\title{
Season effects on the composition of milk produced by a Holstein herd managed under semi-confinement followed by compost bedded dairy barn management
}

\section{Efeito das estações do ano sobre a composição do leite de rebanho Holandês manejado em semiconfinamento e posteriormente em compost bedded dairy barn}

\author{
Carol Thaís Weber ${ }^{1}$; Catia Letícia Corrêa Schneider²; Marcos Busanello \\ Júlia Laize Bandeira Calgaro ${ }^{2}$; Júnior Fioresi ${ }^{1}$; Cássio Rodrigo Gehrke ${ }^{1}$; \\ Jardel Menegazzi da Conceição ${ }^{1}$; Ione Maria Pereira Haygert-Velho ${ }^{4 *}$
}

\section{Highlights:}

Somatic cell count and total bacterial count increased under the CBDB system.

No differences were found for other milk variables between the two systems.

Milk was of a higher quality in winter and spring compared with summer and autumn.

\begin{abstract}
Here, we studied the composition of milk produced by a Holstein herd in the municipality of Nova Boa Vista, Rio Grande do Sul (RS), Brazil. The herd was first managed under a semi-confinement system and subsequently, in a compost bedded dairy barn system to facilitate animal management and, more importantly, family work. We monitored milk production by the herd under a semi-confinement system from January 2013 through September 2015, and then under a compost bedded dairy barn system from October 2015 through December 2017. The seasons of the year were spring (October to December), summer (January to March), autumn (April to June), and winter (July to September). Our results showed an increase in somatic cell count and total bacterial count with the change from semi-confinement to the compost bedded dairy barn system, possibly due to management factors; however, no changes were observed for any other of the variables under study, including lactose, fat, protein, and total solids. In addition, season markedly influenced milk composition and quality; thus, in winter and spring, milk was of a higher quality, whereas in the hotter months of summer and autumn fodder quality and availability, and the incidence of mastitis, as reflected by somatic cell count, affected milk quality negatively.
\end{abstract}

Key words: Total bacterial count. Somatic cell count. Fat. Facilities. Lactose. Protein. Breed.

\footnotetext{
1 Discentes do Curso de Graduação em Zootecnia, Universidade Federal de Santa Maria, UFSM, Campus de Palmeira das Missões, Palmeira das Missões, RS, Brasil. E-mail: webercarol13@gmail.com; juniorfioresi@yahoo.com.br; gehrkecassio@hotmail.com; j.menegazzi@hotmail.com

2 Discentes do Curso de Mestrado do Programa de Pós-Graduação em Agronegócios, UFSM, Campus de Palmeira das Missões, Palmeira das Missões, RS, Brasil. E-mail: catiaschneidervet@gmail.com; julia_calgaro@hotmail.com

3 Discente do Curso de Doutorado do Programa de Pós-Graduação em Ciência Animal e Pastagens, Universidade de São Paulo, USP, Escola Superior de Agricultura Luiz de Queiroz, ESALQ, Piracicaba, SP, Brasil. E-mail: marcosbusanello@usp.br

${ }^{4}$ Prof $^{\mathrm{a}}$, Departamento de Zootecnia e Ciências Biológicas, UFSM, Campus de Palmeira das Missões, Palmeira das Missões, RS, Brasil. E-mail: ione.h.velho@ufsm.br

* Author for correspondence
} 


\section{Resumo}

Objetivou-se estudar a composição do leite de um rebanho da raça Holandês no município de Nova Boa Vista - RS que era manejado em sistema semiconfinado e posteriormente evoluiu para Compost Bedded Dairy Barn (CBDB) como forma de facilitar o manejo dos animais e principalmente amenizar o trabalho da família. Os dados utilizados são referentes à composição e qualidade do leite entre os meses de janeiro de 2013 a outubro de 2015 em sistema semiconfinado e de novembro de 2015 a dezembro de 2017 em sistema confinado CBDB. As estações do ano foram consideradas da seguinte forma: Primavera (outubro, novembro e dezembro), Verão (janeiro, fevereiro e março), Outono (abril, maio e junho) e Inverno (julho, agosto e setembro). Os resultados mostraram um aumento da contagem de células somáticas (CCS) e da contagem bacteriana (CBT) com a mudança do sistema semiconfinado para o CBDB, ou seja, estes indicadores foram prejudicados quando as vacas estavam em sistema de $\mathrm{CBDB}$, possivelmente em função dos fatores de manejo, porém, não havendo diferenças para as demais variáveis (lactose, gordura, proteína e EST). Além disso, as estações do ano influenciam a qualidade e composição do leite, sendo que no inverno e na primavera o leite apresentava melhor qualidade uma vez que nos meses mais quentes (verão e outono) a qualidade das forragens e a insciência de mastites (refletida na CCS) foram fatores determinantes.

Palavras-chave: Contagem bacteriana total. Contagem de células somáticas. Gordura. Instalações. Lactose. Proteína.

\section{Introduction}

Milk production and dairy consumption in Brazil increased by $673 \%$ and $240 \%$ over the last five decades (1961-2015), respectively, markedly affecting economic and social performance (Vilela, Resende, Leite, \& Alves, 2017). Because of the importance of the milk production chain (MPC) in Brazil, since 2002 the Ministério da Agricultura, Pecuária e Abastecimento (MAPA) has tried to standardize the quality of milk and dairy products through normative instruction (IN) $\mathrm{N}^{\mathrm{o}} 51$ and later IN $N^{\circ} 62$ and $\mathrm{N}^{\mathrm{o}} 76$ (Instrução Normativa $\mathrm{n}^{\mathrm{o}}$ 51, 2002; Instrução Normativa $n^{\circ} 62$, 2011; Instrução Normativa $n^{\circ} 76,2018$ ), as these parameters affect the routine of rural properties and can influence foreign trade. According to Assis, Ferreira, Martins and Schneider (2016), the increase in national milk production will reduce the importation of dairy products, thereby generating economic and social benefits, in addition to exerting a multiplier effect on the economy.

The MPC is a promising approach to minimize the rural exodus from dairy farming because dairy activity enables daily harvests (Voges, Thaler, \& Kazama, 2015). However, based on the socioeconomic reports of the MPC in Rio Grande do Sul published by the Instituto Gaúcho do Leite [IGL], Empresa de Assistência Técnica e Extensão Rural/RS [EMATER/RS] e Associação Sulina de Crédito e Assistência Rural [ASCAR], (2015) and Empresa de Assistência Técnica e Extensão Rural/ RS [EMATER/RS], (2017), 18,959 farms have abandoned milk production, which has therefore become a more specialized practice. Indeed, most of the current dairy herds are made up of animals of the Holstein (60.8\%) and Jersey (16.9\%) breeds in Rio Grande do Sul, Brazil.

In the United States of America, Capper, Cady and Bauman (2009) reported an overall change in animal genetic profile from $54 \%$ of the herds comprising small breeds, such as Jersey, Guernsey, and Ayrshire in 1944, to $90 \%$ comprising the Holstein breed in 2007. However, to achieve such a change, it was necessary to change the environment, especially in relation to dietary supply, which in $1944\left(2,074 \mathrm{~kg}\right.$ of milk cow $\left.{ }^{-1} \mathrm{y}^{-1}\right)$ comprised more concentrated pastures, whereas in $2007(9,193 \mathrm{~kg}$ of milk cow ${ }^{-1} \mathrm{y}^{-1}$ ) it had moved to totally mixed feed under a confinement system. In addition to changes in feeding quantity and quality, cows were protected 
from heat and cold stress to maintain thermal homeostasis. The evolution of milk cattle facilitated the commercialization of genetic engineering products developed in the United States of America.

Although a large proportion of Brazilian dairy farmers commonly acquire bull semen from the North American Holstein breeds, in which progeny evaluations are usually held under confined systems and, therefore, in controlled environments, in Brazil, most cows are inserted in exclusively pastoral or semiconfined systems. However, a significant part of the diet is provided by pasture. Therefore, the zone of thermal neutrality is not guaranteed, whereby maximal phenotype expression (National Research Council [NRC], 2001) may become limited and, consequently, the effects on biological functioning (health) may be dynamically and interrelatedly altered; whereby negative effects might occur within a short period (24 h), and organism responses to cope with heat stress may be activated (Polsky \& von Keyserlingk, 2017).

The variation in ambient temperature and relative humidity over the seasons alters milk production and composition (Fagan, Jobim, Calixto, Silva, \& Santos, 2010; Gantner, Mijić, Kuterovac, Solić, \& Gantner, 2011; Gantner et al., 2017), including fatty acid profile (Vargas et al., 2015).

While studying a herd managed under a semiconfinement system in the northwest region of Rio Grande do Sul between January 2014 and December 2016, Stürmer, Busanello, Velho, Heck and HaygertVelho (2018), concluded that $10.2 \%$ of the variation in milk composition, pricing, and production was explained by climatic variables, among which, average, minimum, and maximum temperatures, and temperature-humidity index were the most influential. This finding highlighted the importance of the maintenance of thermoneutrality, which is more easily attained in confined systems. Because of the large number of rural properties specializing in the migration of dairy cattle to the compostbedded dairy barn system (CBDB) in Rio Grande do
Sul, we studied season and breeding system effects on milk composition from a Holstein herd in the municipality of Nova Boa Vista, Rio Grande do Sul, which was initially managed under a semiconfined system and later moved to a CBDB system.

\section{Material and Methods}

The database was provided by the Fritzen farm, located in the Noroeste Rio-grandense mesorregion, Nova Boa Vista municipality $\left(27^{\circ} 58^{\prime} 08.63\right.$ " S; $52^{\circ} 57$ '17.45” W; $467 \mathrm{~m}$ a.s.1.), Rio Grande do Sul, Brazil. The longitudinal retrospective study was described according to the recommendations of Sargeant and O'Connor (2014). The climate of the region is characterized as Cfa (subtropical humid with hot summers and without a defined dry season) according to the Köppen classification, with an average annual rainfall of 1,029 $\mathrm{mm}$ (Alvares, Stape, Sentelhas, Gonçalves, \& Sparovek, 2013).

We measured milk composition and quality from January 2013 to October 2015 under a semiconfined system, and from November 2015 to December 2017 under a CBDB confined system. The seasons were divided into spring (October to December), summer (January to March), autumn (April to June), and winter (July to September). On average, the herd was composed of 30 lactating cows throughout the experimental period.

Fishbone milking was performed at 07:00 and at 17:00 hours; in Brazilian summertime the latter was changed to $18: 00$ hours. A collection cooler with capacity for $840 \mathrm{~L}$ was used and the milk was collected daily by the purchasing company. The pre-dipping method was used to clean teats with individual moistened towels, which were immersed in neutral detergent and water for each animal. After milking, post-dipping was conducted using an iodine solution to protect against pathogens until sphincter closure, thereby avoiding contamination.

In relation to sanitary management, the herd was vaccinated according to the official schedule 
of the Inspetoria Veterinária da Secretaria da Agricultura, Pecuária e Irrigação do Estado do Rio Grande do Sul. Females were vaccinated against brucellosis, along with the dehorning of the animals, at an approximate age of three months. A further mandatory vaccine for foot-and-mouth disease was administered in May and November. Vaccinations against symptomatic carbuncle were administered to all animals over three months of age and repeated every six months until two years of age; vaccinations against leptospirosis were administered annually. To reduce the incidence of mastitis within the herd, milking was performed in the following order: healthy cows, cows that had presented clinical mastitis in the current lactation and been treated and, finally, those with clinical mastitis currently undergoing treatment. Clinical symptoms of clinical mastitis included a blackbacked chest. Every 15 d, the California Mastitis Test was performed to diagnose possible cases of subclinical mastitis.

\section{Semiconfined management}

In the semiconfined production system (altogether 33 months, from January 2013 to October 2015), animals grazed in the morning and at dusk during the cooler hours of the day. During the spring and summer seasons, sorghum (Sorghum bicolor) and tifton 85 (Cynodon spp.) pastures were used, while black oats (Avena strigosa) and annual ryegrass (Lolium multiflorum) were used during autumn and winter. Throughout the year, cows had access to a picket fence with water and shade. Corn silage and concentrate were supplied individually after morning (07:00) and afternoon (17:00 or 18:00) milking. The milking system used was the bucket to foot, parallel model (side by side).

\section{Compost bedded dairy barn management}

The CBDB management system (altogether 27 months, from November 2015 to December 2017) on the property used an adapted shed (15 $\mathrm{m}$ wide $\times 20 \mathrm{~m}$ long, north to south orientation), formerly used to store hay and agricultural implements. The shed had a right foot $6 \mathrm{~m}$ high, a 9-m high ridge vent, curtains on the sides, and six fans for climate control and comfort.

In the CBDB system, the compost bedded area provided per cow for rest ranged from $9 \mathrm{~m}^{2}$ to $14 \mathrm{~m}^{2}$. The materials used for bedding consisted in wood shavings and sawdust incorporated monthly and revolved two to three times a day to aid fermentation and control of undesirable microorganisms. The compost bedded shed contained two collective drinking troughs and a collective concrete feedingtrough in which cows received a mixed diet of corn silage, hay, and concentrate. Cows were fed in the morning after milking, in the afternoon, and at night to stimulate feed voluntary intake. Only lactating cows were managed under this system, while dry cows were kept in a pasture area planted with Cynodon dactylon and received concentrate and Cynodon dactylon hay. Considering the entire study period, the mean number of cows in the compost bedded shed was 30, ranging from 25 to 35 cows).

\section{Sampling and composition of milk}

Milk composition data refers to three monthly milk subsamples collected from the cooling tank, from January 2013 to December 2017. The three subsamples constituted a monthly sample. Milk collection was carried out by a representative of the property that bought the natural raw materials of said property. The analyses were carried out by the Laboratório de Serviços de Rebanhos Leiteiros da Universidade de Passo Fundo to determine the levels of milk fat, protein, lactose, defatted dry extract (DDE), total dry extract (TDE), somatic cell count (SCC), and total bacterial count (TBC).

\section{Statistical analysis}

Descriptive statistics analysis (PROC MEANS, SAS software) of milk composition variables was followed by the application of a generalized linear 
mixed model (PROC GLIMMIX, SAS) to determine any differences in milk components among seasons and between the semiconfined and the CBDB management systems. In this model, seasons were the fixed effects, while the breeding system and the interaction between season and system were considered as the random effects, and the effects of the different months were used as repeated measures. We used the first order autoregressive variance-covariance matrix, as it was the best fit of the model according to the Akaike and Bayesian information criteria (AIC and BIC, respectively) (Wolfinger, 1993). For SCC and TBC, the lognormal distribution was used for modelling, while all other variables showed a normal distribution. Normality was determined using histograms, and the ShapiroWilk test (PROC UNIVARIATE, SAS) for model residues and variables for correlation analysis. When necessary, outliers were excluded. When significant, differences among seasons and between systems were verified using the Tukey-Kramer multiple comparisons test. When an interaction between season and production system was found, the interaction was used to obtain the comparisons. All analyses were performed in SAS software, version 9.1 (Statistical Analysis System [SAS], 2012). For all analyses, significant statistical differences were considered at the $0.05(5 \%)$ level of probability.

\section{Results and Discussion}

The similarity between the averages and medians for TDE, DDE, lactose, fat, and protein content in milk (Table 1) confirms that the variables showed a normal distribution. The three values that were considered undesirable were the maximum registered for SCC in the semiconfined system, and $\mathrm{SCC}$ and $\mathrm{TBC}$ in the CBDB system, respectively; however, since this was a retrospective longitudinal study of five consecutive years of evaluation, these values were no reason for concern. Mean SCC increased by 56.41 thousand cells under CBDB relative to semi-confinement. The other values were in compliance with IN $\mathrm{N}^{\circ} 62$ and $\mathrm{N}^{\circ} 76$ dictated by MAPA (Instrução Normativa ${ }^{\circ} 62,2011$; Instrução Normativa $\left.n^{\circ} 76,2018\right)$, largely as a result of family management of the herd. It is important to emphasize that at Fritzen farm, morning milking is performed later (07:00) than in adjacent properties or than reported in the literature (i.e. between 05:00 and 05:30 hours). A similar practice is normal in the Noroeste Rio-grandense mesoregion (HaygertVelho et al., 2018; Botton et al., 2019). Although only slight, this change in milking schedule affects the well-being of people and enables voluntary intake of feed by cows early in the morning (Van Soest, 1994), as it is consistent with the natural timing of the main daily meals for ruminants.

The season of the year interfered (Table 2) with TDE levels $(p=0.0075)$, lactose $(p=0.0018)$, fat $(\mathrm{p}=0.0051)$, protein $(\mathrm{p}=0.0198)$, and SCC $(\mathrm{p}=$ 0.0152 ) contents due to the cultivation of different plant species during the hot (spring and summer) and cold (autumn and winter) seasons. During semi-confinement, such variations were larger because of the cultivation of annual pastures, such as sorghum (Sorghum bicolor), oats (Avena sp.), and ryegrass (Lolium multiflorum). On the other hand, under $\mathrm{CBDB}$ management, variations in roughage decreased, as the diet was totally mixed, and corn silage was preferred but was not supplied all year round. During all the years this evaluation was conducted (2013-2017), ryegrass or tifton hay (Cynodon sp.) was supplied to provide physically effective fibre to the herd, thereby avoiding abrupt variations in ruminal $\mathrm{pH}$. 
Table 1

Descriptive statistics of milk production by a Holstein herd handled first in a semiconfined system and then in a compost bedded dairy barn (CBDB) system, between January 2013 and December 2017 in Nova Boa Vista, Rio Grande do Sul, Brazil

\begin{tabular}{|c|c|c|c|c|c|c|}
\hline \multirow{2}{*}{ Variable } & \multicolumn{6}{|c|}{ Descriptive statistics } \\
\hline & $\mathrm{N}$ & Minimum & Mean & Median & Maximum & Standard deviation \\
\hline \multicolumn{7}{|c|}{$\begin{array}{c}\text { Semiconfined system } \\
\text { (January 2013-September 2015) }\end{array}$} \\
\hline Total dry extract (\%) & 31 & 11.82 & 12.75 & 12.76 & 13.85 & 0.39 \\
\hline Defatted dry extract (\%) & 31 & 8.60 & 8.93 & 8.90 & 9.31 & 0.16 \\
\hline Lactose (\%) & 31 & 4.35 & 4.53 & 4.54 & 4.64 & 0.08 \\
\hline Fat $(\%)$ & 32 & 3.20 & 3.83 & 3.85 & 4.59 & 0.29 \\
\hline Protein $(\%)$ & 31 & 3.02 & 3.39 & 3.40 & 3.82 & 0.16 \\
\hline $\operatorname{SCC}\left(\times 1000\right.$ cells $\left.\mathrm{mL}^{-1}\right)$ & 33 & 163.00 & 358.33 & 349.00 & 691.00 & 116.82 \\
\hline TBC $\left(\times 1000 \mathrm{CFU} \mathrm{mL}^{-1}\right)$ & 33 & 3.00 & 127.58 & 12.00 & 26.00 & 6.64 \\
\hline \multicolumn{7}{|c|}{$\begin{array}{c}\text { CBDB system } \\
\text { (October 2015-December 2017) }\end{array}$} \\
\hline Total dry extract (\%) & 27 & 12.10 & 12.83 & 12.81 & 13.50 & 0.32 \\
\hline Defatted dry extract $(\%)$ & 27 & 8.61 & 8.96 & 8.99 & 9.20 & 0.15 \\
\hline Lactose $(\%)$ & 27 & 4.48 & 4.55 & 4.54 & 4.67 & 0.05 \\
\hline Fat $(\%)$ & 27 & 3.45 & 3.88 & 3.85 & 4.31 & 0.22 \\
\hline Protein $(\%)$ & 27 & 3.17 & 3.38 & 3.36 & 3.62 & 0.13 \\
\hline $\mathrm{SCC}\left(\times 1000\right.$ cells $\left.\mathrm{mL}^{-1}\right)$ & 27 & 219.00 & 414.74 & 424.00 & 784.00 & 121.02 \\
\hline TBC $\left(\times 1000 \mathrm{CFU} \mathrm{mL} \mathrm{mL}^{-1}\right)$ & 27 & 31.00 & 84.78 & 52.00 & 343.00 & 81.05 \\
\hline
\end{tabular}

$\mathrm{SCC}=$ somatic cell count; $\mathrm{TBC}=$ total bacterial count.

Table 2

Average values for the composition of milk produced by a Holstein breed based on season of the year and handled first in a semiconfined system and then in a compost bedded dairy barn (CBDB) system between January 2013 and December 2017, in Nova Boa Vista, Rio Grande do Sul, Brazil

\begin{tabular}{ccccccccccc}
\hline \multirow{2}{*}{ Variable } & \multicolumn{4}{c}{ Season } & \multicolumn{3}{c}{ Production system } & \multicolumn{3}{c}{ Value probability } \\
\cline { 2 - 9 } & Spring & Summer & Autumn & Winter & Semiconfined & CBDB & Season & PS & $\begin{array}{c}\text { Season } \times \\
\text { PS }\end{array}$ \\
\hline TDE (\%) & $12.49 \mathrm{~b}$ & $12.84 \mathrm{a}$ & $13.02 \mathrm{a}$ & $12.81 \mathrm{ab}$ & 12.73 & 12.85 & 0.0075 & 0.1407 & 0.3596 \\
Lactose (\%) & $4.57 \mathrm{a}$ & $4.50 \mathrm{~b}$ & $4.49 \mathrm{~b}$ & $4.59 \mathrm{a}$ & 4.53 & 4.55 & 0.0018 & 0.1299 & 0.4071 \\
Fat (\%) & $3.64 \mathrm{~b}$ & $3.93 \mathrm{a}$ & $4.05 \mathrm{a}$ & $3.81 \mathrm{ab}$ & 3.82 & 3.90 & 0.0051 & 0.2041 & 0.9377 \\
Protein (\%) & $3.28 \mathrm{~b}$ & $3.42 \mathrm{ab}$ & $3.46 \mathrm{a}$ & $3.38 \mathrm{ab}$ & 3.38 & 3.39 & 0.0198 & 0.9096 & 0.1589 \\
$\mathrm{SCC}^{1}$ & $341.00 \mathrm{ab}$ & $404.00 \mathrm{ab}$ & $438.00 \mathrm{a}$ & $308 \mathrm{~b} .00$ & 334.00 & 404.00 & 0.0152 & 0.0214 & 0.4050 \\
TBC $^{2}$ & 28.00 & 21.00 & 28.00 & 31.00 & 10.00 & 67.00 & 0.2057 & $<0.0001$ & 0.9152 \\
\hline
\end{tabular}

$\mathrm{TDE}=$ Total dry extract; $\mathrm{SCC}=$ somatic cell count; $\mathrm{TBC}=$ total bacterial count.

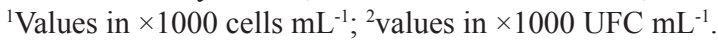

Means followed by different letters indicate statistical difference based on the Tukey-Kramer test. 
Fritzen farm did not send feed or diet samples for determination of the corresponding chemical composition as most rural properties of the region do. Nonetheless, the feed produced on the property showed desirable characteristics (e.g. low fibre content) as a function of soil fertility. Chemical and organic fertilizers obtained by composting pig manure and CBDB were used and periodically spread over the ground.

In a study of the effects of the application of domestic ruminant slurry (cattle and sheep) on plant production in Integrated Agricultural Production Systems, Crotty et al. (2014) verified an efficient use of organic fertilizers produced on rural properties. Furthermore, such use influenced the sustainability of agricultural systems by triggering cascade benefits, such as feeding of the herd, application of waste to the soil, and the concomitant reduction of negative impacts of such wastes on the environment, and (re)initiating the (re)cycling of nutrients by producing fertilizers in bulk. Similarly, while studying nitrogen efficiency of dairy cattle manure for fodder crops, Perramon, Bosch-Serra, Domingo-Olivé and Boixadera (2016) concluded that it is possible to increase nitrogen recycling in a system, thereby favouring system sustainability. The above effects probably occur on the Fritzen property, since the Integrated System of Agricultural Production on the property involves the finishing of swine, breeding of milk cattle, production of pasture and preserved hay for animal feed, and the use of swine and dairy cattle manure as fertilizer for the growth of corn silage.

While evaluating the effects of the preserved bulky ingredients on the production and composition of milk of Holstein cows between January 2000 and December 2015 under experimental conditions in Brazil, Alessio et al. (2018) verified that the supply of corn silage as the sole source of roughage or in combination with one or two bulky ingredients improved milk production and composition because it is a high energy density feed. Consistently, using statistical analysis to evaluate the technological level employed for corn silage production in 40 milk-producing properties in the South Region of Brazil, Silva, Jobim, Poppi, Tres and Osmari (2015) verified that the first component was characterized by the size of the farm (ha) and crop management during silage, represented by the localization indicators (state/meteorological conditions), hybrid genetics company, and crop management. Further, the second component responded to production technology and silage management indicators represented by the use of inoculants. Thus, corn silage is one of the most used ingredients for feeding and nutrition of milk cows due to their genetic symmetry with breeds that are specialized in milk production.

The production systems under evaluation here differed only for SCC $(p=0.0214)$ and TBC $(p<$ 0.0001 ), with the CBDB group showing the greater values, probably because farmers are still in the process of learning to adapt to the newly adopted system, which is a relatively recent occurrence in Brazil and Rio Grande do Sul, where maximum SCC and TBC values of 784,000 cells $\mathrm{mL}^{-1}$ and 343,000 UFC $\mathrm{mL}^{-1}$ were observed, respectively. These values are higher than those indicated by IN $N^{o} 62$ and $N^{\circ} 76$ (Instrução Normativa $n^{\circ} 62$, 2011; Instrução Normativa $n^{\circ} 76,2018$ ) published by MAPA, as in some periods the number of animals in the CBDB exceeded the ideal number, consequently, the rest area available per cow decreased and production increased, therefore altering the fermentation dynamics of the litter and microorganism populations. Another factor influencing the outcome was the replacement of bedding; during some periods, the materials normally used (wood shavings and sawdust) were not found in the region, resulting in a bed with a higher moisture content, which directly influenced bed decomposition. According to Black, Taraba, Day, Damasceno and Bewley (2013), the depth of bed revolving, frequency, and space per cow increases bed temperature during decomposition, decreasing its humidity and the average filth score 
of the herd. However, as the CBDB system on the Fritzen farm was one of the first to be implemented in the region, proper compost-bed management was still undergoing optimization. Although there are several studies dealing with CBDB under temperate conditions (Endres \& Barberg, 2007; Lobeck, Endres, Shane, Godden, \& Fetrow, 2011), very few studies have been undertaken under Brazilian subtropical conditions, particularly when facilities are adapted for each rural property. However, it is worth noting that, on average, in both systems the values of SCC and TBC remained within the limits recommended by IN $\mathrm{N}^{\circ} 62$ and $\mathrm{N}^{\mathrm{o}} 76$, namely, 500,000 cells $\mathrm{mL}^{-1}$ and 300,000 CFU $\mathrm{mL}^{-}$ 1, respectively (Instrução Normativa $n^{\circ}$ 62, 2011; Instrução Normativa $n^{\circ} 76,2018$ ).

The only variable that showed significant interaction effects between management system and season of the year was $\operatorname{DDE}(p=0.0171)$; the unfolding of the interaction is shown in Table 3. In the summer, DDE was higher in the CBDB system than in the semi-confinement system; however, there was no difference between the two systems in any other season. It is possible that there was an increase in DDE in the summer due to the reduction of milk production in the CBDB system in relation to the semi-confinement system caused by the higher occurrence of mastitis, as evidenced by the values of SCC and TBC (Table 2). Although CBDB is a system which allows the improvement of well-being, especially by minimizing heat stress, if bed management (tilting and replenishing) is not performed properly and routinely, and cow number is above optimal, problems such as mastitis occur frequently. According to Galama (2011), $12.5 \mathrm{~m}^{2}$ per cow is an ideal space for CBDB using sawdust as a bed. In a semiconfined system, animals are affected by high ambient temperature and relative humidity, which directly influence voluntary intake (Tylutki et al., 2008), with negative repercussions on milk production and composition (von Keyserlingk \& Weary, 2017). Further, milk composition differed between summer and spring in the CBDB system, likely due to the differences between the diets provided to the animals in each case; additionally, bed management is reportedly easier in summer. Thus, together, a well-managed bed material and an adequate animal stocking will improve cow hygiene, thereby reducing the incidence of mastitis and ultimately improving milk quality and animal well-being (Leso et al., 2019).

Table 3

Average values of the defatted dry extract (DDE) of the Holstein breed during different seasons under a semiconfined system followed by a compost bedded dairy barn system between January 2013 and December 2017, in Nova Boa Vista, Rio Grande do Sul, Brazil

\begin{tabular}{cccc}
\hline \multirow{2}{*}{ Season } & \multicolumn{2}{c}{ Production system } & \multirow{2}{*}{ Mean } \\
\cline { 2 - 3 } & Semiconfined & Compost Bedded Dairy Barn & 8.85 \\
\hline Spring $^{1}$ & $8.89 \mathrm{ABa}$ & $8.81 \mathrm{Ba}$ & 8.96 \\
Summer $^{2}$ & $8.82 \mathrm{Ba}$ & $9.09 \mathrm{Ab}$ & 8.97 \\
Autumn $^{3}$ & $8.96 \mathrm{ABa}$ & $8.98 \mathrm{ABa}$ & 9.00 \\
Winter $^{4}$ & $9.01 \mathrm{Aa}$ & $8.98 \mathrm{ABa}$ & \\
\hline Mean & 8.92 & 8.97 & \\
\hline
\end{tabular}

${ }^{1}$ Spring (October, November, December); ${ }^{2}$ Summer (January, February, March); ${ }^{3}$ Autumn (April, May, June); ${ }^{4}$ Winter (July, August, September).

Different lowercase letters after mean values indicate significant differences between systems $(\mathrm{p}<0.05)$ and different uppercase letters indicate significant difference among seasons $(\mathrm{p}<0.05)$ based on the Tukey-Kramer test. 
This study showed that the CBDB system remains a challenge for Brazilian producers. Perhaps the most controversial result was the decrease in milk quality, based on SCC and TBC values. This may be directly related to factors such as animal stocking in the shed, bed wetness, well-being, and disease incidence, mainly mastitis. However, this does not mean that the CBDB system is ineffective but rather, that the challenges owners faced at the beginning of the implementation of the system may have caused the reduction in SCC and TBC, although their values still fell within governmental recommendations. More studies using the CBDB system are needed to generate useful information to aid the decision-making process and the day-today operation of dairy farms. This study reflects the reality of one rural property only; thus, future studies should map more producers to better understand their motivations, perceptions, and results obtained with this system.

\section{Conclusions}

We found an increase in SCC and TBC with the change from a semi-confinement to a CBDB system, possibly due to management factors, particularly, animal stocking and bed management. However, there were no significant differences between systems for any other variable studied (lactose, fat, protein, and TDE). In addition, season influenced milk quality and composition, being of a higher quality in winter and spring, as in the hotter months of summer and autumn the quality of the fodder and the incidence of mastitis (reflected in SCC values) reduced milk quality.

\section{Acknowledgments}

We thankfully acknowledge the Fritzen Farm for sharing their data. This study was financed in part by the Coordenação de Aperfeiçoamento de Pessoal de Nível Superior - Brasil (CAPES; Finance Code 001) with a Doctoral scholarship for Marcos Busanello, who is currently in pursuit of a Doctoral degree in the Animal Sciences and Pastures Program at ESALQ/ USP. We also wish to thank the Fundo de Incentivo à Pesquisa da Universidade Federal de Santa Maria (FIPE - UFSM) for the support granted to academic Júlia Laize Bandeira Calgaro and Cássio Rodrigo Gehrke. Lastly, we thank the Conselho Nacional de Desenvolvimento Científico e Tecnológico for the support granted to academic Jardel Menegazzi da Conceição.

\section{References}

Alessio, D. R. M., Velho, J. P., Silveira, V. C. P., Knob, D. A., Busanello, M., Tambara, A. A. C., \& Thaler, A., Neto. (2018). Roughage sources for Holstein cows under experimental feeding conditions in Brazil - a meta-analysis. Semina: Ciências Agrárias, 39(6), 2749-2760. doi: 10.5433/1679-0359.2018v39n 6 p2749

Alvares, C. A., Stape, J. L., Sentelhas, P. C., Gonçalves, J. L. de M., \& Sparovek, G. (2013). Köppen's climate classification map for Brazil. Meteorologische Zeitschrift, 22(6), 711-728. doi: 10.1127/09412948/2013/0507

Assis, J. de, Ferreira, J. D., Martins, H. H., \& Schneider, M. B. (2016). Cadeia produtiva do leite no Brasil no contexto do comércio internacional. Revista de Ciências Empresariais da UNIPAR, 17(1), 63-93. doi: 10.25110/receu.v17i1.5199

Black, R. A., Taraba, J. L., Day, G. B., Damasceno, F. A., \& Bewley, J. M. (2013). Compost bedded pack dairy barn management, performance, and producer satisfaction. Journal of Dairy Science, 96(12), 80608074. doi: $10.3168 /$ jds.2013-6778

Botton, F. S., Alessio, D. R. M., Busanello, M., Schneider, C. L. C., Stroeher, F. H., \& Haygert-Velho, I. M. P. (2019). Relationship of total bacterial and somatic cell counts with milk production and composition - multivariate analysis. Acta Scientiarum. Animal Sciences,41, e42568. doi: 10.4025/actascianimsci. v41i1.42568

Capper, J. L., Cady, R. A., \& Bauman, D. E. (2009). The environmental impact of dairy production: 1944 compared with 2007. Journal of Animal Science, 87(6), 2160-2167. doi: 10.2527/jas.2009-1781 
Crotty, F. V., Fychan, R., Theobald, V. J., Sanderson, R., Chadwick, D. R., \& Marley, C. L. (2014). The impact of using alternative forages on the nutrient value within slurry and its implications for forage productivity in agricultural systems. Plos One, 9(5), e97516. doi: 10.1371/journal.pone.0097516

Empresa de Assistência Técnica e Extensão Rural/ RS. (2017). Relatório socioeconômico da cadeia produtiva do leite no Rio Grande do Sul. Porto Alegre, RS: EMATER/RS.

Endres, M. I., \& Barberg, A. E. (2007). Behavior of dairy cows in an alternative bedded-pack housing system. Journal of Dairy Science, 90(9), 4192-4200. doi: 10.3168/jds.2006-751

Fagan, E. P., Jobim, C. C., Calixto, M., Jr., Silva, M. S. da, \& Santos, G. T. dos. (2010). Fatores ambientais e de manejo sobre a composição química do leite em granjas leiteiras do Estado do Paraná, Brasil. Acta Scientiarum. Animal Sciences, 32(3), 309-316. doi: 10.4025/actascianimsci.v32i3.8570

Galama, P. (2011). Prospects for bedded pack barns for dairy cattle. Lelystad, The Netherlands: Wageningen UR Livestock Research.

Gantner, V., Bobic, T., Gantner, R., Gregic, M., Kuterovac, K., Novakovic, J., \& Potocnik, K. (2017). Differences in response to heat stress due to production level and breed of dairy cows. International Journal of Biometeorology, 61(9), 1675-1685. doi: 10.1007/ s00484-017-1348-7

Gantner, V., Mijić, P., Kuterovac, K., Solić, D., \& Gantner, R. (2011). Temperature-humidity index values and their significance on the daily production of dairy cattle. Mljekarstvo, 61(1), 56-63.

Haygert-Velho, I. M. P., Conceição, G. M. da, Cosmam, L. C., Alessio, D. R. M., Busanello, M., Sippert, M. R.,... Velho, J. P. (2018). Multivariate analysis relating milk production, milk composition, and seasons of the year. Anais da Academia Brasileira de Ciências, 90(4), 3839-3852. doi: 10.1590/00013765201820180345

Instituto Gaúcho do Leite, Empresa de Assistência Técnica e Extensão Rural/RS e Associação Sulina de Crédito e Assistência Rural (2015). Relatório socioeconômico da cadeia produtiva do leite no Rio Grande do Sul. Porto Alegre, Rio Grande do Sul: IGL, EMATER/RS, ASCAR.

Instrução Normativa $n^{\circ}$ 51, de 20 de setembro de 2002. Brasília: Diário Oficial da União 1, 13.

Instrução Normativa $n^{\circ}$ 62, de 30 de dezembro de 2011. Brasília: Diário Oficial da União 1, 8-10.
Instrução Normativa $n^{\circ}$ 76, de 26 de novembro de 2018. Brasília: Diário Oficial da União 1, 9-10.

Leso, L., Barbari, M., Lopes, M. A., Damasceno, F. A., Galama, P., Taraba, J. L., \& Kuipers, A. (2019). Invited review: Compost-bedded pack barns for dairy cows. Journal of Dairy Science, 103(2), 10721099. doi: $10.3168 /$ jds.2019-16864

Lobeck, K. M., Endres, M. I., Shane, E. M., Godden, S. M., \& Fetrow, J. (2011). Animal welfare in crossventilated, compost-bedded pack, and naturally ventilated dairy barns in the upper Midwest. Journal of Dairy Science, 94(11), 5469-5479. doi: 10.3168/ jds.2011-4363

National Research Council (2001). Nutrient of requirements of dairy cattle (7nd ed.). Washington, DC: National Academic Press.

Perramon, B., Bosch-Serra, À. D., Domingo-Olivé, F., \& Boixadera, J. (2016). The efficiency of nitrogen in cattle manures when applied to a double-annual forage cropping system. Grass and Forage Science, 72(4), 676-690. doi: 10.1111/gfs.12269

Polsky, L., \& von Keyserlingk, M. A. G. (2017). Invited review: effects of heat stress on dairy cattle welfare. Journal of Dairy Science, 100(11), 8645-8657. doi: 10.3168/jds.2017-12651

Sargeant, J. M., \& O'Connor, A. M. (2014). Issues of reporting in observational studies in veterinary medicine. Preventive Veterinary Medicine, 113(3), 323-330. doi: 10.1016/j.prevetmed.2013.09.004

Silva, M. S. J. da, Jobim, C. C., Poppi, E. C., Tres, T. T., \& Osmari, M. P. (2015). Production technology and quality of corn silage for feeding dairy cattle in Southern Brazil. Revista Brasileira de Zootecnia, 44(9), 303-313. doi: 10.1590/S180692902015000900001

Statistical Analysis System (2002). Statistical analysis system user's guide: statistics, version 8.2. Cary, USA: SAS Institute.

Stürmer, M., Busanello, M., Velho, J. P., Heck, V. I., \& Haygert-Velho, I. M. P. (2018). Relationship between climatic variables and the variation in bulk tank milk composition using canonical correlation analysis. International Journal of Biometeorology, 62(9), 1663-1674. doi: 10.1007/s00484-018-1566-7

Tylutki, T. P., Fox, D. G., Durbal, V. M., Tedeschi, L. O., Russell, J. B., Van Amburgh, M. E.,... Pell, A. N. (2008). Cornell net carbohydrate and protein system: a model for precision feeding of dairy cattle. Animal Feed and Science Technology, 143(1-4), 174-202. doi: 10.1016/j.anifeedsci.2007.05.010 
Van Soest, P. J. (1994). Nutritional ecology of the ruminant. Ithaca, USA: Cornell University Press.

Vargas, D. P. de, Nörnberg, J. L., Scheibler, R. B., Schafhauser, J., Jr., Rizzo, F. A., \& Wagner, R. (2015) Qualidade e potencial nutracêutico do leite bovino em diferentes sistemas de produção e estações do ano. Pesquisa Agropecuária Brasileira, 50(12), 12081219. doi: 10.1590/S0100-204X2015001200011

Vilela, D., Resende, J. C. de, Leite, J. B., \& Alves, E. (2017). A evolução do leite no Brasil em cinco décadas. Revista de Política Agrícola, 26(1), 5-24.

Voges, J. G., Thaler, A., Neto, \& Kazama, D. C. da S. (2015). Qualidade do leite e a sua relação com o sistema de produção e a estrutura para ordenha. Revista Brasileira de Ciência Veterinária, 22(3-4), 171-175. doi: 10.4322/rbcv.2016.009
Von Keyserlingk, M. A. G., \& Weary, D. M. (2017). A 100-Year Review: Animal welfare in the Journal of Dairy Science The first 100 years. Journal of Dairy Science, 100(12), 10432-10444. doi: 10.3168/ jds.2017-13298

Wolfinger, R. (1993). Covariance structure selection in general mixed models. Communications in Statistics - Simulation and Computation, 22(4), 1079-1106. doi: 10.1080/03610919308813143 
